\title{
Triclinic $\mathrm{Na}_{3.12} \mathrm{Co}_{2.44}\left(\mathrm{P}_{2} \mathrm{O}_{7}\right)_{2}$ as a High Redox Potential Cathode Material for Na-Ion Batteries
}

\author{
Kwang-Ho Ha ${ }^{\dagger}$, Mi-Sook Kwon ${ }^{\dagger}$, and Kyu Tae Lee* \\ School of Chemical and Biological Engineering, Institute of Chemical Processes, Seoul National University, 1 Gwanak-ro, \\ Gwanak-gu, Seoul 08826, Republic of Korea
}

\begin{abstract}
Two types of sodium cobalt pyrophosphates, triclinic $\mathrm{Na}_{3.12} \mathrm{Co}_{2.44}\left(\mathrm{P}_{2} \mathrm{O}_{7}\right)_{2}$ and orthorhombic $\mathrm{Na}_{2} \mathrm{CoP}_{2} \mathrm{O}_{7}$, are compared as high-voltage cathode materials for Na-ion batteries. $\mathrm{Na}_{2} \mathrm{CoP}_{2} \mathrm{O}_{7}$ shows no electrochemical activity, delivering negligible capacity. In contrast, $\mathrm{Na}_{3.12} \mathrm{Co}_{2.44}\left(\mathrm{P}_{2} \mathrm{O}_{7}\right)_{2}$ exhibits good electrochemical performance, such as high redox potential at $c a$. $4.3 \mathrm{~V}$ (vs. $\mathrm{Na} / \mathrm{Na}^{+}$) and stable capacity retention over 50 cycles, although $\mathrm{Na}_{3.12} \mathrm{Co}_{2.44}\left(\mathrm{P}_{2} \mathrm{O}_{7}\right)_{2}$ delivered approximately $40 \mathrm{~mA} \mathrm{~h} \mathrm{~g}^{-1}$. This is attributed to the fact that $\mathrm{Na}_{2} \mathrm{CoP}_{2} \mathrm{O}_{7}(\sim 3.1 \AA)$ has smaller diffusion channel size than $\mathrm{Na}_{3.12} \mathrm{Co}_{2.44}\left(\mathrm{P}_{2} \mathrm{O}_{7}\right)_{2}$ $(\sim 4.2 \AA)$. Moreover, the electrochemical performance of $\mathrm{Na}_{3.12} \mathrm{Co}_{2.44}\left(\mathrm{P}_{2} \mathrm{O}_{7}\right)_{2}$ is examined using $\mathrm{Na}$ cells and Li cells. The overpotential of $\mathrm{Na}$ cells is smaller than that of $\mathrm{Li}$ cells. This is due to the fact that $\mathrm{Na}_{3.12} \mathrm{Co}_{2.44}\left(\mathrm{P}_{2} \mathrm{O}_{7}\right)_{2}$ has a smaller charge transfer resistance and higher diffusivity for $\mathrm{Na}^{+}$ions than $\mathrm{Li}^{+}$ions. This implies that the large channel size of $\mathrm{Na}_{3.12} \mathrm{Co}_{2.44}\left(\mathrm{P}_{2} \mathrm{O}_{7}\right)_{2}$ is more appropriate for $\mathrm{Na}^{+}$ions than $\mathrm{Li}^{+}$ions. Therefore, $\mathrm{Na}_{3.12} \mathrm{Co}_{2.44}\left(\mathrm{P}_{2} \mathrm{O}_{7}\right)_{2}$ is considered a promising

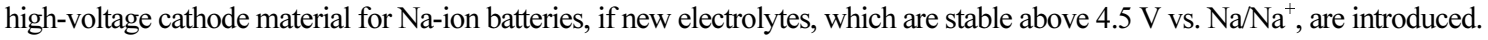

Keywords : Na-ion batteries, Cathode, Off-stoichiometry, Pyrophosphate

Received : 11 November 2019, Accepted : 2 January 2020

\section{Introduction}

Recently, Na-ion batteries have been considered as a promising alternative to $\mathrm{Li}$-ion batteries because abundance in sodium precursors can lead to a cost reduction [1-4]. In addition, the existence of a database of electrode materials for Li-ion batteries can promote the development of electrode materials for $\mathrm{Na}$-ion batteries, since the chemistry of Na-ion batteries is similar to that of Li-ion batteries. Drawing inspiration from previously reported cathode materials for Li-ion batteries, many research groups have reported various cathode materials for $\mathrm{Na}$-ion batteries. These include $\mathrm{Na}_{\mathrm{x}} \mathrm{CoO}_{2}[5,6], \mathrm{Na}_{\mathrm{x}} \mathrm{CrO}_{2}$ and $\mathrm{Na}_{\mathrm{x}}$ $\mathrm{NiO}_{2}$ [7], $\alpha-\mathrm{NaFeO}_{2}$ [8], $\mathrm{Na}_{\mathrm{x}} \mathrm{VO}_{2}[9,10], \mathrm{Na}_{0.44} \mathrm{MnO}_{2}$ [11], $\mathrm{Na}_{2 / 3}\left[\mathrm{Fe}_{1 / 2} \mathrm{Mn}_{1 / 2}\right] \mathrm{O}_{2}$ [12], $\mathrm{Na}_{1-\mathrm{x}} \mathrm{Ni}_{0.5} \mathrm{Mn}_{0.5} \mathrm{O}_{2}$ [13], $\mathrm{NaCo}_{1 / 3} \mathrm{Ni}_{1 / 3} \mathrm{Mn}_{1 / 3} \mathrm{O}_{2}$ [14], $\mathrm{NaMPO}_{4}(\mathrm{M}=\mathrm{Fe}$,

$\dagger$ These two authors contributed equally to this work. *E-mail address: ktlee@snu.ac.kr

DOI: https://doi.org/10.33961/jecst.2019.00633

This is an open-access article distributed under the terms of the Creative Commons Attribution Non-Commercial License (http://creativecommons.org/licenses/by-nc/4.0) which permits unrestricted non-commercial use, distribution, and reproduction in any medium, provided the original work is properly cited.
$\mathrm{Mn})$ [15], $\mathrm{A}_{2} \mathrm{MPO}_{4} \mathrm{~F}(\mathrm{~A}=\mathrm{Na}, \mathrm{Li}, \mathrm{M}=\mathrm{Fe}, \mathrm{Mn}, \mathrm{Co}$, Ni) [16], $\mathrm{NaVPO}_{4} \mathrm{~F}$ [17], $\mathrm{Na}_{1.5} \mathrm{VOPO}_{4} \mathrm{~F}_{0.5}$ [18], $\mathrm{Na}_{3} \mathrm{~V}_{2}\left(\mathrm{PO}_{4}\right)_{2} \mathrm{~F}_{3}[19,20], \mathrm{Na}_{3} \mathrm{Fe}_{3}\left(\mathrm{PO}_{4}\right)_{4}$ [21], $\mathrm{Na}_{2} \mathrm{FeP}_{2} \mathrm{O}_{7}$ [22], $t-\mathrm{Na}_{2}(\mathrm{VO}) \mathrm{P}_{2} \mathrm{O}_{7}$ [23], and $\mathrm{Na}_{2} \mathrm{MnP}_{2} \mathrm{O}_{7}[24,25]$. Our group also reported a new pyrophosphate cathode material (triclinic $\mathrm{Na}_{4-\alpha} \mathrm{M}_{2+\alpha /}$ ${ }_{2}\left(\mathrm{P}_{2} \mathrm{O}_{7}\right)_{2}$ where $2 / 3 \leq \alpha \leq 7 / 8$ and $\mathrm{M}=\mathrm{Fe}, \mathrm{Fe}_{0.5} \mathrm{Mn}_{0.5}$, or $\mathrm{Mn}$ ) and showed promising electrochemical performance including negligible capacity fading over 60 cycles and good rate performance [26]. Then, Niu et al. and Chen et al. optimized the electrochemical performance of $\mathrm{Na}_{3.12} \mathrm{Fe}_{2.44}\left(\mathrm{P}_{2} \mathrm{O}_{7}\right)_{2}[27,28]$. However, its specific energy $\left(3.0 \mathrm{~V} \times c a .85 \mathrm{~mA} \mathrm{~h} \mathrm{~g}^{-1}\right)$ is still smaller than that of $\mathrm{LiFePO}_{4}(3.4 \mathrm{~V} \times c a$. $160 \mathrm{~mA} \mathrm{~h} \mathrm{~g}^{-1}$ ), which is used in Li-ion batteries. Not only $\mathrm{Na}_{3.12} \mathrm{Fe}_{2.44}\left(\mathrm{P}_{2} \mathrm{O}_{7}\right)_{2}$ but the majority of cathode materials for $\mathrm{Na}$-ion batteries display lower energy densities when compared to those used in Li-ion batteries; thus, an improvement in energy density is vital for commercialization of $\mathrm{Na}$-ion batteries. This can be achieved by either increasing the reversible capacity or the redox potential. It is well known that the redox potential of $\mathrm{Co}^{2+} / \mathrm{Co}^{3+}$ in phosphate-based 
materials for Li-ion batteries is higher than those of $\mathrm{Fe}^{2+} / \mathrm{Fe}^{3+}$ and $\mathrm{Mn}^{2+} / \mathrm{Mn}^{3+}$ [29]. Therefore, in this report, we introduce the $\mathrm{Co}$ analogue $\left(\mathrm{Na}_{3.12} \mathrm{Co}_{2.44}\left(\mathrm{P}_{2} \mathrm{O}_{7}\right)_{2}\right)$ of triclinic $\mathrm{Na}_{3.12} \mathrm{Fe}_{2.44}\left(\mathrm{P}_{2} \mathrm{O}_{7}\right)_{2}$ as a high-voltage cathode material for the improvement in energy density. Moreover, triclinic $\mathrm{Na}_{3.12} \mathrm{Co}_{2.44}\left(\mathrm{P}_{2} \mathrm{O}_{7}\right)_{2}$ was also compared with orthorhombic $\mathrm{Na}_{2} \mathrm{CoP}_{2} \mathrm{O}_{7}$ to investigate the effect of crystal structure on electrochemical performance. It was known that three crystal structures of sodium cobalt pyrophosphates $\left(\mathrm{Na}_{2} \mathrm{CoP}_{2} \mathrm{O}_{7}\right)$ exist: orthorhombic $\left(P n a 2_{1}\right)$, tetragonal $\left(\mathrm{P4}_{2} / \mathrm{mmm}\right)$, and triclinic $(P-1)$ structures [30-32]. Whereas the electrochemical performance of nanosized orthorhombic $\mathrm{Na}_{2} \mathrm{CoP}_{2} \mathrm{O}_{7}$ has been reported [33], the synthesis and electrochemical performance of triclinic $\mathrm{Na}_{3.12} \mathrm{Co}_{2.44}\left(\mathrm{P}_{2} \mathrm{O}_{7}\right)_{2}$ have not yet been studied to the best of our knowledge. Furthermore, we demonstrate that $\mathrm{Na}_{3.12} \mathrm{Co}_{2.44}\left(\mathrm{P}_{2} \mathrm{O}_{7}\right)_{2}$ has an appropriate channel size for $\mathrm{Na}^{+}$ions through comparison of the electrochemical behaviors of $\mathrm{Na}_{3.12} \mathrm{Co}_{2.44}\left(\mathrm{P}_{2} \mathrm{O}_{7}\right)_{2}$ in $\mathrm{Na}$-ion and $\mathrm{Li}$-ion cells.

\section{Experimental}

\subsection{Synthesis}

Triclinic $\mathrm{Na}_{3.12} \mathrm{Co}_{2.44}\left(\mathrm{P}_{2} \mathrm{O}_{7}\right)_{2}$ and orthorhombic $\mathrm{Na}_{2} \mathrm{CoP}_{2} \mathrm{O}_{7}$ were synthesized through a conventional solid-state method. Stoichiometric amounts of sodium carbonate $\left(\mathrm{Na}_{2} \mathrm{CO}_{3}\right.$, Sigma-Aldrich, $\geq$ $99.5 \%)$, cobalt nitrate hexahydrate $\left(\mathrm{Co}\left(\mathrm{NO}_{3}\right)_{2} \cdot 6 \mathrm{H}_{2} \mathrm{O}\right.$, Sigma-Aldrich, 98+\%), and ammonium phosphate dibasic $\left(\left(\mathrm{NH}_{4}\right)_{2} \mathrm{HPO}_{4}\right.$, Sigma-Aldrich, 98+\%) were mixed, and then heated at $300^{\circ} \mathrm{C}$ for 6 hours and $600^{\circ} \mathrm{C}$ for 12 hours in $\mathrm{Ar}$ atmosphere.

\subsection{Chemical de/sodiation processes}

Chemical oxidations of $\mathrm{Na}_{3.12} \mathrm{Co}_{2.44}\left(\mathrm{P}_{2} \mathrm{O}_{7}\right)_{2}$ (as well as the electrochemical charging processes) to $\mathrm{Na}_{3.12-\mathrm{x}}$ $\mathrm{Co}_{2.44}\left(\mathrm{P}_{2} \mathrm{O}_{7}\right)_{2}(\mathrm{x}=\sim 1)$ and $\mathrm{Na}_{3.12-\mathrm{y}} \mathrm{Co}_{2.44}\left(\mathrm{P}_{2} \mathrm{O}_{7}\right)_{2}(\mathrm{y}=$ $\sim 2)$ is performed using nitronium tetrafluoroborate $\left(\mathrm{NO}_{2} \mathrm{BF}_{4}, 95+\%\right.$, Sigma-Aldrich) with equimolar amounts, stirred with acetonitrile (AN) solvent for 3 hours, then filtered and washed with ethanol. In the same way, sodium iodide (NaI, $\geq 99.5 \%$, SigmaAldrich) is added for chemical reduction (electrochemical discharging processes) with AN, stirred for 5 hours. Changes in atomic composition of $\mathrm{Na}_{3.12} \mathrm{Co}_{2.44}\left(\mathrm{P}_{2} \mathrm{O}_{7}\right)_{2}$ were estimated using an inductively coupled plasma-mass spectrometer (ICPMS, Perkin-Elmer NexION 350D).

\subsection{Materials characterization}

Powder X-Ray diffraction (XRD) data were collected on a Bruker D2 Phaser diffractometer using $\mathrm{Cu}-\mathrm{K} \alpha$ radiation $(\lambda=1.5418 \AA$ ) operated from $2 \theta=10$ - $80^{\circ}$. Rietveld refinements were performed using powder XRD patterns with the TOPAS program. The morphologies of powders were examined using the Hitachi S-4800 Field Emission Scanning Electron Microscopy (FE-SEM).

\subsection{Electrochemical characterization}

Each active material (70 wt.\%) was mixed with carbon black (Super-P, 15 wt.\%) and polyvinylidene fluoride (PVdF, 15 wt.\%) in 1-methyl-2-pyrrolidinone solvents (NMP, Sigma-Aldrich, anhydrous, 99\%). The slurries were coated on Al foil as a current collector. Electrochemical performances of $\mathrm{Na}_{3.12} \mathrm{Co}_{2.44}\left(\mathrm{P}_{2} \mathrm{O}_{7}\right)_{2}$ and $\mathrm{Na}_{2} \mathrm{CoP}_{2} \mathrm{O}_{7}$ were examined using coin cells (CR2032 type). Na and Li metals were used as counter electrodes for $\mathrm{Na}$-ion and $\mathrm{Li}$-ion half-cells, respectively. A $0.8 \mathrm{M}$ solution of sodium hexafluorophosphate $\left(\mathrm{NaPF}_{6}\right)$ dissolved in a mixture $(1: 1, \mathrm{v} / \mathrm{v})$ of ethylene carbonate (EC) and propylene carbonate (PC), with $5 \mathrm{wt} . \%$ of fluoroethylene carbonate (FEC) and 1 wt.\% of tris(trimethylsilyl)phosphite (TMSP) additives, and $1.3 \mathrm{M}$ of lithium hexafluorophosphate $\left(\mathrm{LiPF}_{6}\right)$ dissolved in a mixture $(3: 2: 5, \mathrm{v} / \mathrm{v} / \mathrm{v})$ of ethylene carbonate, ethyl methyl carbonate (EMC), and diethyl carbonate (DEC) were used as electrolytes for Na-ion and Li-ion half-cells, respectively. Galvanostatic experiments were performed at the current density of $4.75 \mathrm{~mA} \mathrm{~g}^{-1}$ ( $c a$. 0.05 $\mathrm{C}$-rate) in the voltage ranges from 2.4 to $4.5 \mathrm{~V}$ vs. $\mathrm{Na} / \mathrm{Na}^{+}$and from 2.7 to $4.8 \mathrm{~V}$ vs. $\mathrm{Li} / \mathrm{Li}^{+}$. Furthermore, the potentiostatic intermittent titration technique (PITT) was performed to estimate diffusion coefficients. The potential step of $10 \mathrm{mV}$ was applied at various depth of discharge states. Each potential step was applied until the current density was less than $0.75 \mathrm{~mA} \mathrm{~g}^{-1}$. Electrochemical impedance spectroscopy (EIS) was carried out in the frequency range from $300 \mathrm{kHz}$ to $1 \mathrm{mHz}$ with voltage amplitude of 5 $\mathrm{mV}$ using the BioLogic SP-150.

\section{Results and Discussion}

Two types of sodium cobalt pyrophosphates, triclinic $\mathrm{Na}_{3.12} \mathrm{Co}_{2.44}\left(\mathrm{P}_{2} \mathrm{O}_{7}\right)_{2}$ and orthorhombic $\mathrm{Na}_{2} \mathrm{CoP}_{2} \mathrm{O}_{7}$, were synthesized through a conventional 


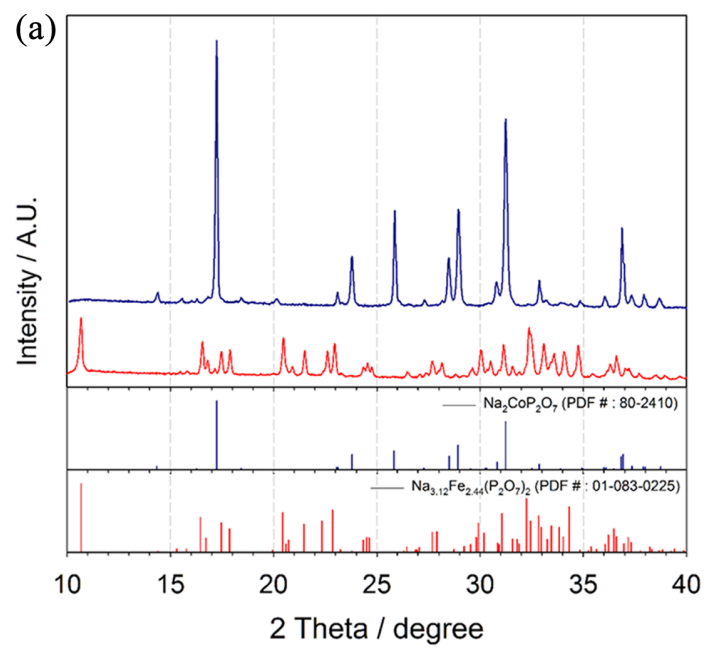

(b)

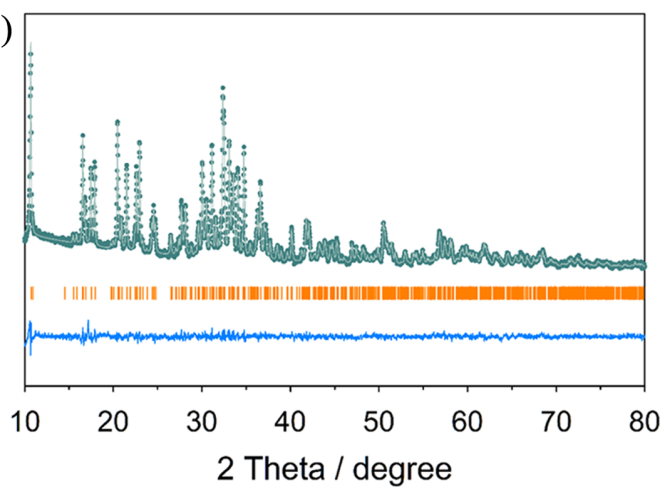

Fig. 1. XRD patterns of $\mathrm{Na}_{3.12} \mathrm{Co}_{2.44}\left(\mathrm{P}_{2} \mathrm{O}_{7}\right)_{2}$ and $\mathrm{Na}_{2} \mathrm{CoP}_{2} \mathrm{O}_{7}$ powders, and (b) Rietveld refinement of $\mathrm{Na}_{3.12} \mathrm{Co}_{2.44}\left(\mathrm{P}_{2} \mathrm{O}_{7}\right)_{2}$.

solid-state method via heating at $600^{\circ} \mathrm{C}$ under Ar. Fig. 1(a) shows the X-ray diffraction (XRD) patterns of $\mathrm{Na}_{3.12} \mathrm{Co}_{2.44}\left(\mathrm{P}_{2} \mathrm{O}_{7}\right)_{2}$ and $\mathrm{Na}_{2} \mathrm{CoP}_{2} \mathrm{O}_{7}$, indicating that they contained no impurities. We performed the Rietveld refinement to determine the lattice parameters of $\mathrm{Na}_{3.12} \mathrm{Co}_{2.44}\left(\mathrm{P}_{2} \mathrm{O}_{7}\right)_{2}$ (Fig. 1(b) and Table 1). This revealed that $\mathrm{Na}_{3.12} \mathrm{Co}_{2.44}\left(\mathrm{P}_{2} \mathrm{O}_{7}\right)_{2}$ has a crystal structure similar to triclinic $\mathrm{Na}_{3.12} \mathrm{Fe}_{2.44}\left(\mathrm{P}_{2} \mathrm{O}_{7}\right)_{2}$. However, a slight distortion was observed due to the different ionic size between $\mathrm{Co}$ and Fe. As shown in the crystal structure images (Fig. 2(a), (b), and (c)), $\mathrm{Na}_{3.12} \mathrm{Co}_{2.44}\left(\mathrm{P}_{2} \mathrm{O}_{7}\right)_{2}$ is composed of two centrosymmetrical crowns of $\mathrm{Co}_{2} \mathrm{P}_{4} \mathrm{O}_{20}$ and $\mathrm{Co}_{2} \mathrm{P}_{4} \mathrm{O}_{22}$, and has three dimensional diffusion channels along the [100], [010], and [101] directions. On the other hand, ort-
Table 1. Lattice parameters of $\mathrm{Na}_{3.12} \mathrm{Co}_{2.44}\left(\mathrm{P}_{2} \mathrm{O}_{7}\right)_{2}$ obtained by Rietveld refinement with agreement factors.

\begin{tabular}{cc}
\hline \hline Parameters & $\mathrm{Na}_{3.12} \mathrm{Co}_{2.44}\left(\mathrm{P}_{2} \mathrm{O}_{7}\right)_{2}$ \\
\hline $\mathrm{a} / \AA$ & $6.37314(11)$ \\
$\mathrm{b} / \AA$ & $9.96077(16)$ \\
$\mathrm{c} / \AA$ & $10.96801(20)$ \\
$\alpha /{ }^{\circ}$ & $64.4518(13)$ \\
$\beta /{ }^{\circ}$ & $85.9552(16)$ \\
$\gamma /{ }^{\circ}$ & $73.5350(15)$ \\
${\text { Volume } / \AA^{3}}$ & $565.126(19)$ \\
$\mathrm{R}_{\mathrm{p}} / \%$ & 1.04 \\
$\mathrm{R}_{\mathrm{wp}} / \%$ & 1.38 \\
$\chi^{2}$ & 1.47
\end{tabular}

horhombic $\mathrm{Na}_{2} \mathrm{CoP}_{2} \mathrm{O}_{7}$ has a layered crystal structure having a two-dimensional diffusion path perpendicular to the [010] direction (Fig. 2(d)).

We compared the electrochemical performances of triclinic $\mathrm{Na}_{3.12} \mathrm{Co}_{2.44}\left(\mathrm{P}_{2} \mathrm{O}_{7}\right)_{2}$ and orthorhombic $\mathrm{Na}_{2} \mathrm{CoP}_{2} \mathrm{O}_{7}$, as shown in Fig. 3. Na metal and a $0.8 \mathrm{M}$ solution of $\mathrm{NaPF}_{6}$ dissolved in a mixture solvent of EC and PC 1:1 (v/v) were used as a counter electrode and electrolyte, respectively. FEC and TMSP were added as electrolyte additives to improve the electrochemical stability of electrolytes at high voltages [34]. As shown in the voltage profiles and dQ/dV plots of $\mathrm{Na}_{3.12} \mathrm{Co}_{2.44}\left(\mathrm{P}_{2} \mathrm{O}_{7}\right)_{2}$ (Fig. 3(a) and (b)), two plateaus were observed at very high redox potentials of $\sim 3.9$ and $4.3 \mathrm{~V}$ vs. $\mathrm{Na} / \mathrm{Na}^{+}$. This implies that $\mathrm{Na}_{3.12} \mathrm{Co}_{2.44}\left(\mathrm{P}_{2} \mathrm{O}_{7}\right)_{2}$ exhibited a higher redox potential than $\mathrm{Na}_{3.12} \mathrm{Fe}_{2.44}\left(\mathrm{P}_{2} \mathrm{O}_{7}\right)_{2}\left(\sim 3.0 \mathrm{~V}\right.$ vs. $\left.\mathrm{Na} / \mathrm{Na}^{+}\right)$. Although $\mathrm{Na}_{3.12} \mathrm{Co}_{2.44}\left(\mathrm{P}_{2} \mathrm{O}_{7}\right)_{2}$ delivered a smaller reversible capacity (approximately $40 \mathrm{~mA} \mathrm{~h} \mathrm{~g}^{-1}$ ) than $\mathrm{Na}_{3.12} \mathrm{Fe}_{2.44}\left(\mathrm{P}_{2} \mathrm{O}_{7}\right)_{2}\left(\sim 85 \mathrm{~mA} \mathrm{~h} \mathrm{~g}^{-1}\right)$, this is attributed to the upper limit of the charging voltage $(4.5 \mathrm{~V}$ vs. $\mathrm{Na} / \mathrm{Na}^{+}$) due to the severe electrolyte decomposition above $4.5 \mathrm{~V}$. $\mathrm{Na}_{3.12} \mathrm{Co}_{2.44}\left(\mathrm{P}_{2} \mathrm{O}_{7}\right)_{2}$ also showed excellent reversibility with negligible capacity fading over 50 cycles, although the coulombic efficiency was not sufficiently high because of electrolyte decomposition (Fig. 3(d)). In contrast to triclinic $\mathrm{Na}_{3.12} \mathrm{Co}_{2.44}\left(\mathrm{P}_{2} \mathrm{O}_{7}\right)_{2}$, layered $\mathrm{Na}_{2} \mathrm{CoP}_{2} \mathrm{O}_{7}$ did not deliver any observable reversible capacity in the voltage range between 2.4 and $4.5 \mathrm{~V}$ vs. $\mathrm{Na} / \mathrm{Na}^{+}$(Fig. $3(\mathrm{c}))$. The poor electrochemical activity of $\mathrm{Na}_{2} \mathrm{CoP}_{2} \mathrm{O}_{7}$ is attributed to very slow kinetics result- 
(a)

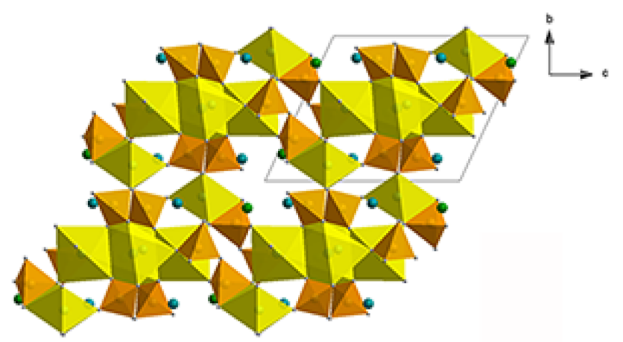

(c)

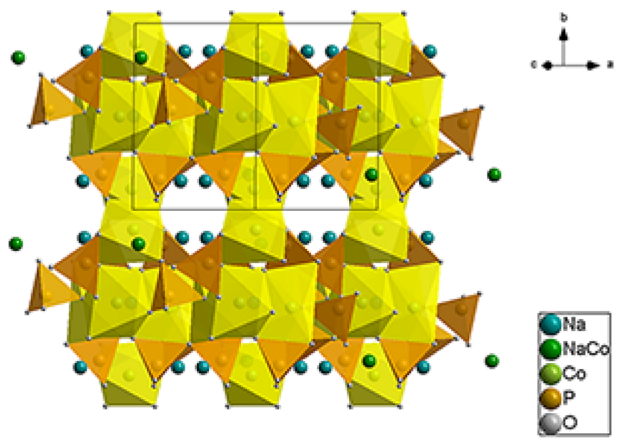

(b)

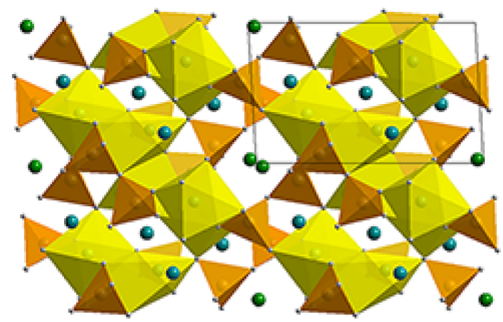

(d)

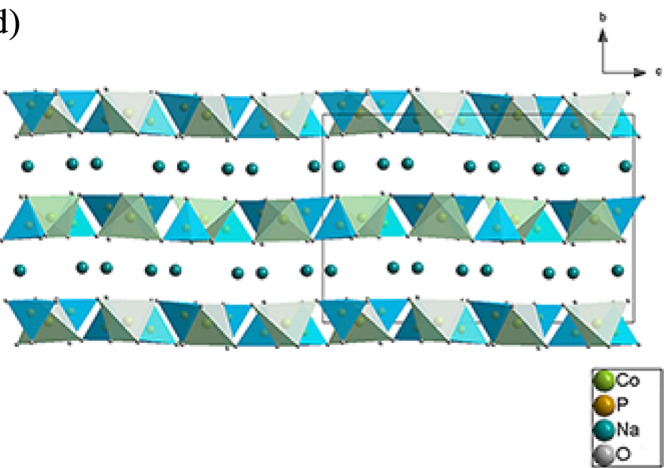

Fig. 2. Crystal structures of $\mathrm{Na}_{3.12} \mathrm{Co}_{2.44}\left(\mathrm{P}_{2} \mathrm{O}_{7}\right)_{2}$ along the (a) [100], (b) [010], and (c) [101] directions and crystal structure of (d) $\mathrm{Na}_{2} \mathrm{CoP}_{2} \mathrm{O}_{7}$ along the [100] direction.

(a)

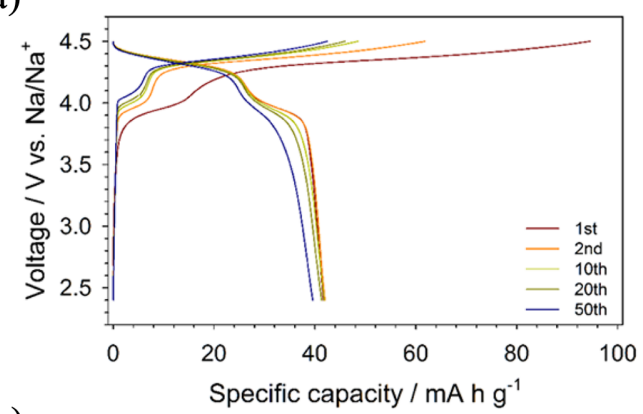

(c)

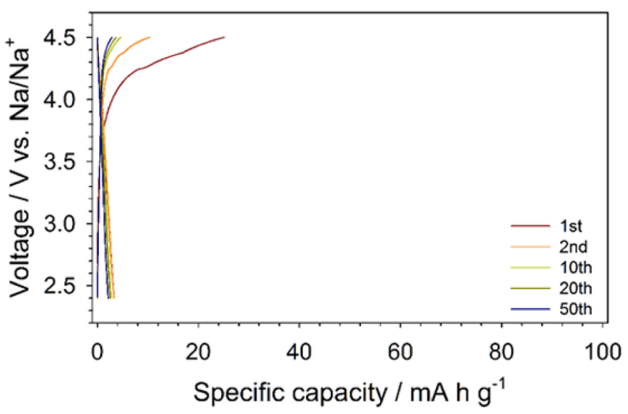

(b)

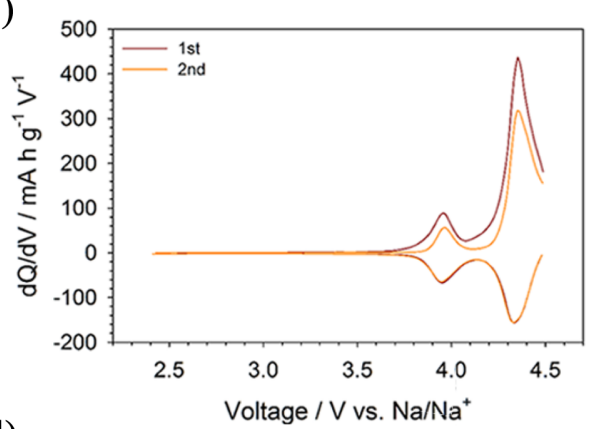

(d)

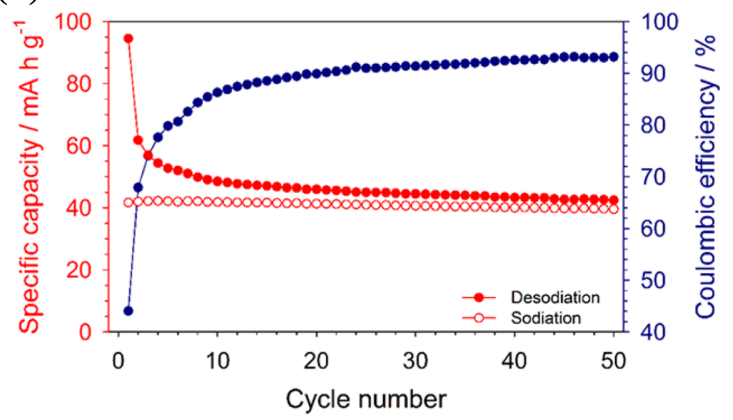

Fig. 3. (a) Voltage profiles and (b) $d Q / d V$ plots of $\mathrm{Na}_{3.12} \mathrm{Co}_{2.44}\left(\mathrm{P}_{2} \mathrm{O}_{7}\right)_{2}$ for Na-ion cells, (c) voltage profiles of $\mathrm{Na}_{2} \mathrm{CoP}_{2} \mathrm{O}_{7}$ for Na-ion cells, and (d) cycle performance and coulombic efficiency of $\mathrm{Na}_{3.12} \mathrm{Co}_{2.44}\left(\mathrm{P}_{2} \mathrm{O}_{7}\right)_{2}$ for Na-ion cells. 

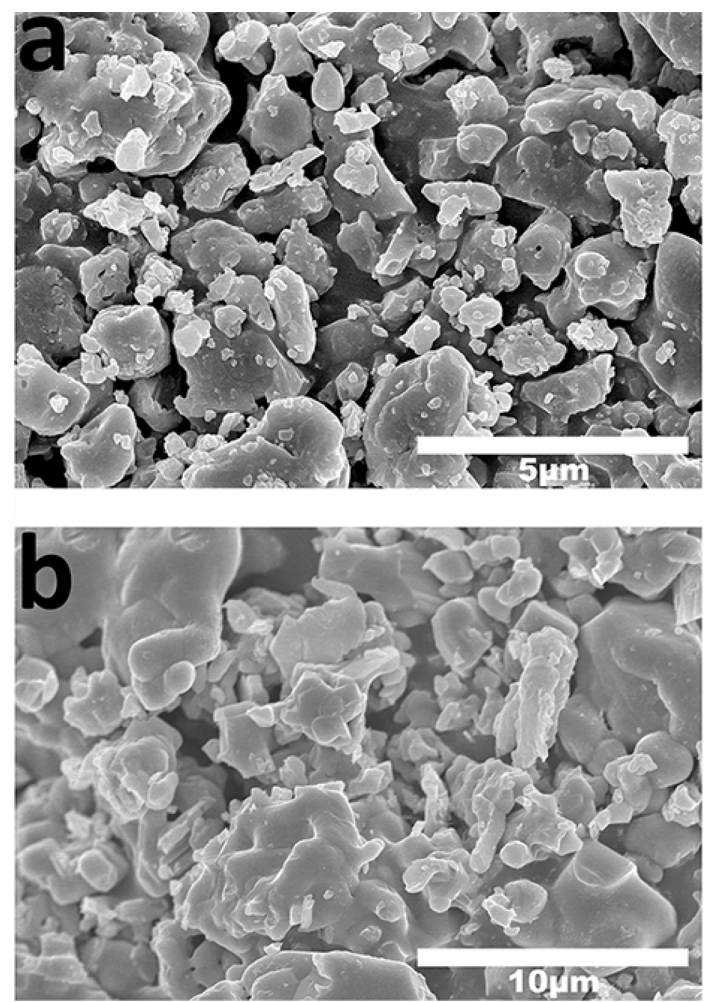

Fig. 4. $\mathrm{SEM}$ images of (a) $\mathrm{Na}_{3.12} \mathrm{Co}_{2.44}\left(\mathrm{P}_{2} \mathrm{O}_{7}\right)_{2}$ and (b) $\mathrm{Na}_{2} \mathrm{CoP}_{2} \mathrm{O}_{7}$ powders.

ing from the high activation energy for the diffusion of $\mathrm{Na}^{+}$ions due to the small channel size $(\sim 3.1 \AA)$; note that the channel size of $\mathrm{Na}_{3.12} \mathrm{Co}_{2.44}\left(\mathrm{P}_{2} \mathrm{O}_{7}\right)_{2}$ is $\sim 4.2$ A. Since $\mathrm{Na}_{3.12} \mathrm{Co}_{2.44}\left(\mathrm{P}_{2} \mathrm{O}_{7}\right)_{2}$ and $\mathrm{Na}_{2} \mathrm{CoP}_{2} \mathrm{O}_{7}$ have similar particle sizes that ranges from hundreds of nanometers to a few micrometers, as shown in the SEM images (Fig. 4), the different electrochemical activities of $\mathrm{Na}_{3.12} \mathrm{Co}_{2.44}\left(\mathrm{P}_{2} \mathrm{O}_{7}\right)_{2}$ and $\mathrm{Na}_{2} \mathrm{CoP}_{2} \mathrm{O}_{7}$ were not due to the difference in the particle sizes.

Moreover, $\mathrm{Na}_{3.12} \mathrm{Co}_{2.44}\left(\mathrm{P}_{2} \mathrm{O}_{7}\right)_{2}$ and $\mathrm{Na}_{2} \mathrm{CoP}_{2} \mathrm{O}_{7}$ were examined as cathode materials for $\mathrm{Li}$-ion batteries (Fig. 5). Li metal and a $1.3 \mathrm{M}$ solution of $\mathrm{LiPF}_{6}$ dissolved in a mixture solution of EC: EMC: DEC $(3: 2: 5, \mathrm{v} / \mathrm{v} / \mathrm{v})$ were used as a counter electrode and electrolyte, respectively. Li-ion cells of $\mathrm{Na}_{2} \mathrm{CoP}_{2} \mathrm{O}_{7}$ still exhibited no electrochemical activity in the voltage range between 2.7 and $4.8 \mathrm{~V}$ vs. $\mathrm{Li} / \mathrm{Li}^{+}$(Fig. $5(\mathrm{c}))$, which is consistent with the result of $\mathrm{Na}$-ion cells. Li-ion cells of $\mathrm{Na}_{3.12} \mathrm{Co}_{2.44}\left(\mathrm{P}_{2} \mathrm{O}_{7}\right)_{2}$ delivered a reversible capacity of approximately $40 \mathrm{~mA} \mathrm{~h} \mathrm{~g}^{-1}$ (a)

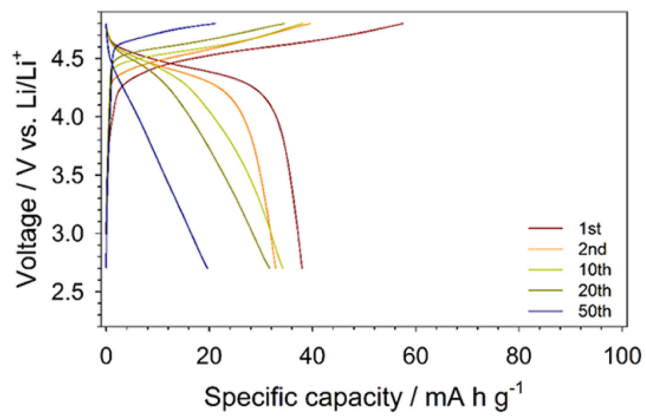

(b)

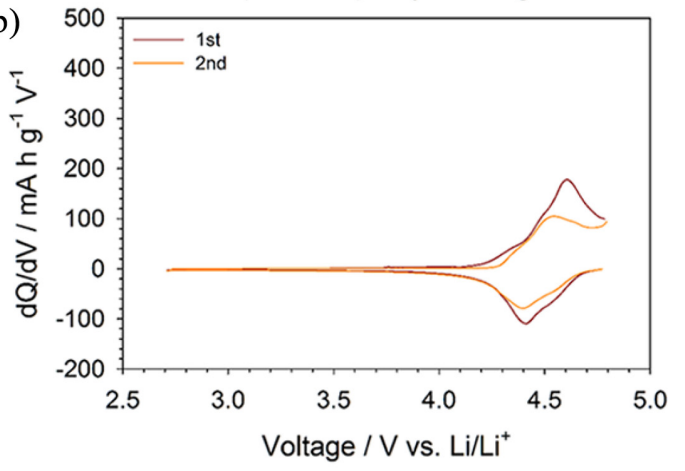

(c)

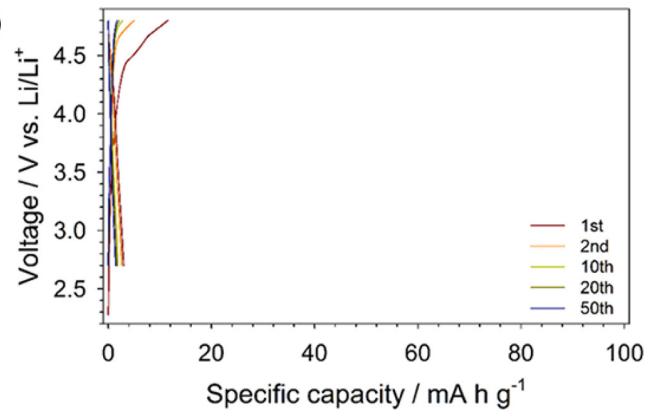

Fig. 5. (a) Voltage profiles and (b) $d Q / d V$ plots of $\mathrm{Na}_{3.12} \mathrm{Co}_{2.44}\left(\mathrm{P}_{2} \mathrm{O}_{7}\right)_{2}$ for Li-ion cells, and (c) voltage profiles of $\mathrm{Na}_{2} \mathrm{CoP}_{2} \mathrm{O}_{7}$ for Li-ion cells.

(Fig. 5(a)), which is similar to its Na-ion cells. However, when compared to the performance for Na-ion cells, $\mathrm{Na}_{3.12} \mathrm{Co}_{2.44}\left(\mathrm{P}_{2} \mathrm{O}_{7}\right)_{2}$ exhibited a larger polarization and poorer capacity retention for Li-ion cells, as shown in the dQ/dV plots (Fig. 3(b) and 5(b)). It is notable that the overpotential of Na-ion cells was smaller than that of Li-ion cells, despite the fact that $\mathrm{Na}^{+}$ions are larger than $\mathrm{Li}^{+}$ions. To understand this behavior, diffusion coefficients and charge transfer resistances were investigated using PITT and EIS, respectively (Fig. 6). The diffusion coefficients $(D)$ were calculated using the equation below with the 


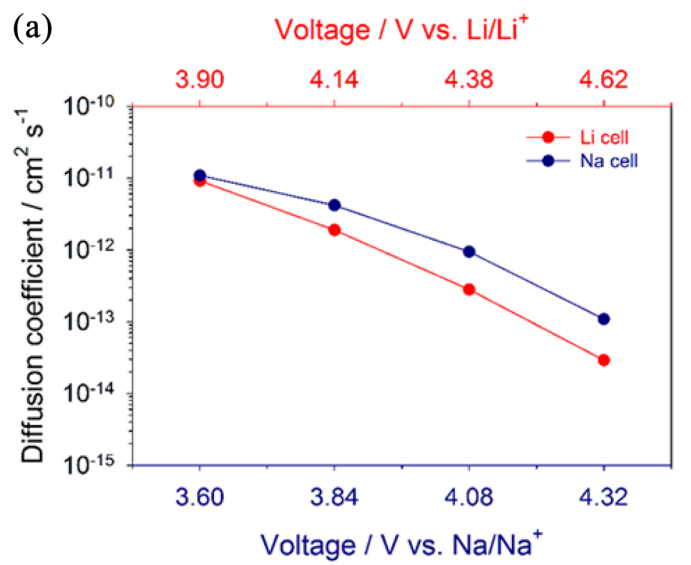

(b)

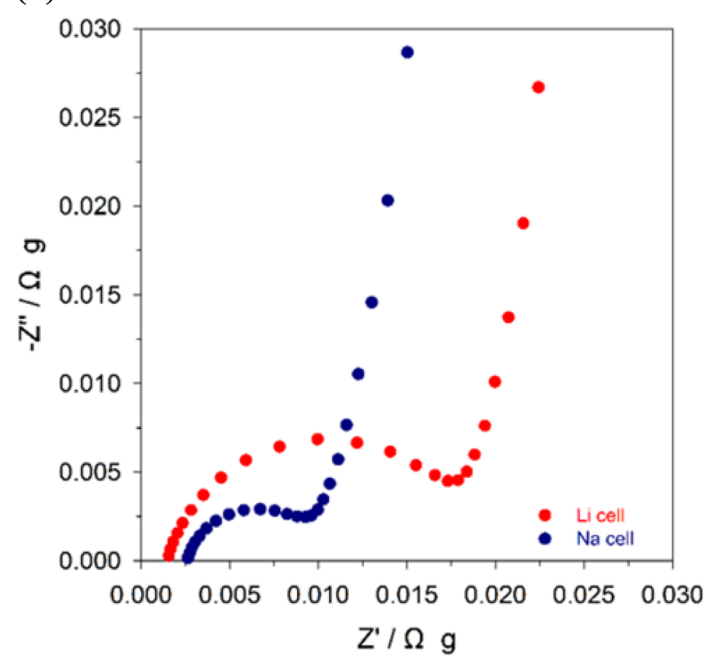

Fig. 6. (a) Diffusion coefficients of $\mathrm{Na}_{3.12} \mathrm{Co}_{2.44}\left(\mathrm{P}_{2} \mathrm{O}_{7}\right)_{2}$ for each cells. (b) Nyquist plots of $\mathrm{Na}_{3.12} \mathrm{Co}_{2.44}\left(\mathrm{P}_{2} \mathrm{O}_{7}\right)_{2}$ using symmetric cells for $\mathrm{Na}$-ion and $\mathrm{Li}$-ion cells.

assumption of the finite diffusion to exclude the effect of surface roughness of particles:

$$
i=\frac{2 n F A D \Delta C}{a} \exp \left[\left(-\frac{\pi^{2} D}{a^{2}}\right) t\right]
$$

where $n$ is an equivalent amount of electrons, $F$ is Faraday constant, $A$ is the surface area of particles, $\Delta C$ is the concentration gradient, and $a$ is a particle radius. The diffusion coefficients of $\mathrm{Li}^{+}$and $\mathrm{Na}^{+}$ions in $\mathrm{Na}_{3.12} \mathrm{Co}_{2.44}\left(\mathrm{P}_{2} \mathrm{O}_{7}\right)_{2}$ were measured using current transients obtained from the PITT (Fig. 6(a)) [35-37]. Diffusion coefficients were calculated from the slopes $\left(-\pi^{2} D / a^{2}\right)$ of $\ln (i \mathrm{mp})$ vs. $t$. Interestingly, the diffusion coefficients of $\mathrm{Na}^{+}$ions were higher than those of $\mathrm{Li}^{+}$ions in $\mathrm{Na}_{3.12} \mathrm{Co}_{2.44}\left(\mathrm{P}_{2} \mathrm{O}_{7}\right)_{2}$. This suggests that the large channel size of $\mathrm{Na}_{3.12} \mathrm{Co}_{2.44}\left(\mathrm{P}_{2} \mathrm{O}_{7}\right)_{2}$ is more suitable for larger $\mathrm{Na}^{+}$ions than $\mathrm{Li}^{+}$ions. This behavior is consistent with $\mathrm{Na}^{+}$-conducting $\beta$ alumina [38-40]; the activation energy of $\mathrm{Na}^{+}$ions for ionic diffusion in $\beta$-alumina is lower than that of $\mathrm{Li}^{+}$ions. This is attributed to the fact that the smaller $\mathrm{Li}^{+}$is less stable in large sites with a high coordination number, resulting in stronger binding with oxygen than that in the case of $\mathrm{Na}^{+}$. In addition, to compare the charge transfer resistances of $\mathrm{Na}_{3.12} \mathrm{Co}_{2.44}\left(\mathrm{P}_{2} \mathrm{O}_{7}\right)_{2}$ between Na cells and Li cells, we performed the EIS analysis using symmetric cells comprising two identical fully charged electrodes. This revealed that $\mathrm{Na}-$ ion cells have a smaller charge transfer resistance than Li-ion cells (Fig. 6(b)). For these reasons, $\mathrm{Na}_{3.12} \mathrm{Co}_{2.44}\left(\mathrm{P}_{2} \mathrm{O}_{7}\right)_{2}$ showed better electrochemical performance for $\mathrm{Na}$-ion batteries, indicating that the structure of $\mathrm{Na}_{3.12} \mathrm{Co}_{2.44}\left(\mathrm{P}_{2} \mathrm{O}_{7}\right)_{2}$ is more suitable for $\mathrm{Na}$-ion batteries.

Since the high charging voltage inevitably leads to the oxidative decomposition of the electrolyte, the electrochemical reaction mechanism of $\mathrm{Na}_{3.12} \mathrm{Co}_{2.44}\left(\mathrm{P}_{2} \mathrm{O}_{7}\right)_{2}$ was investigated through chemical sodiation and desodiation. The redox potentials of oxidizing and reducing agents must be above and below a redox potential of $\mathrm{Na}_{3.12} \mathrm{Co}_{2.44}\left(\mathrm{P}_{2} \mathrm{O}_{7}\right)_{2}(c a$. 3.9 and $4.3 \mathrm{~V}$ vs. $\left.\mathrm{Na} / \mathrm{Na}^{+}\right)$, respectively. For this reation, $\mathrm{NO}_{2} \mathrm{BF}_{4}\left(\mathrm{~V}\left(\mathrm{NO}_{2}{ }^{+} / \mathrm{NO}_{2}\right)=\right.$ ca. $4.8 \mathrm{~V}$ vs. $\mathrm{Na} /$ $\left.\mathrm{Na}^{+}\right)$and $\mathrm{NaI}\left(\mathrm{V}\left(\mathrm{I}_{2} / \mathrm{I}^{-}\right)=\right.$ca. $3.1 \mathrm{~V}$ vs. $\left.\mathrm{Na} / \mathrm{Na}^{+}\right)$were used for chemical desodiation and sodiation, respectively [41]. The sequential formation of $\mathrm{Na}_{3.12} \mathrm{Co}_{2.44}\left(\mathrm{P}_{2} \mathrm{O}_{7}\right)_{2} \rightarrow \mathrm{Na}_{2.5} \mathrm{Co}_{2.44}\left(\mathrm{P}_{2} \mathrm{O}_{7}\right)_{2} \rightarrow$ $\mathrm{Na}_{2.0} \mathrm{Co}_{2.44}\left(\mathrm{P}_{2} \mathrm{O}_{7}\right)_{2} \rightarrow \mathrm{Na}_{2.65} \mathrm{Co}_{2.44}\left(\mathrm{P}_{2} \mathrm{O}_{7}\right)_{2} \rightarrow$ $\mathrm{Na}_{2.75} \mathrm{Co}_{2.44}\left(\mathrm{P}_{2} \mathrm{O}_{7}\right)_{2}$ was obtained via repetitive desodiation and sodiation using equimolar $\mathrm{NO}_{2} \mathrm{BF}_{4}$ and $\mathrm{NaI}$, respectively. The amount of $\mathrm{Na}$ and $\mathrm{Co}$ in $\mathrm{Na}_{3.12-}$ ${ }_{\mathrm{x}} \mathrm{Co}_{2.44}\left(\mathrm{P}_{2} \mathrm{O}_{7}\right)_{2}$ was measured by ICP analysis (Fig. 7(a)). Then, we obtained the XRD patterns of those compositions, as shown in Fig. 7(b). The XRD peaks gradually and reversibly shift as $\mathrm{x}$ in $\mathrm{Na}_{3.12 \text { - }}$ ${ }_{\mathrm{x}} \mathrm{Co}_{2.44}\left(\mathrm{P}_{2} \mathrm{O}_{7}\right)_{2}$ increased and decreased, and we also observed no evidence for a two-phase mixture of the end member phases. This implies that the $\mathrm{Na}_{3.12} \mathrm{Co}_{2.44}\left(\mathrm{P}_{2} \mathrm{O}_{7}\right)_{2}$ electrode proceeds in a one-phase reaction. This solid solution behavior of $\mathrm{Na}_{3.12} \mathrm{Co}_{2.44}\left(\mathrm{P}_{2} \mathrm{O}_{7}\right)_{2}$ was also confirmed by the appearance of sloping voltage profiles (Fig. 3(a)). 

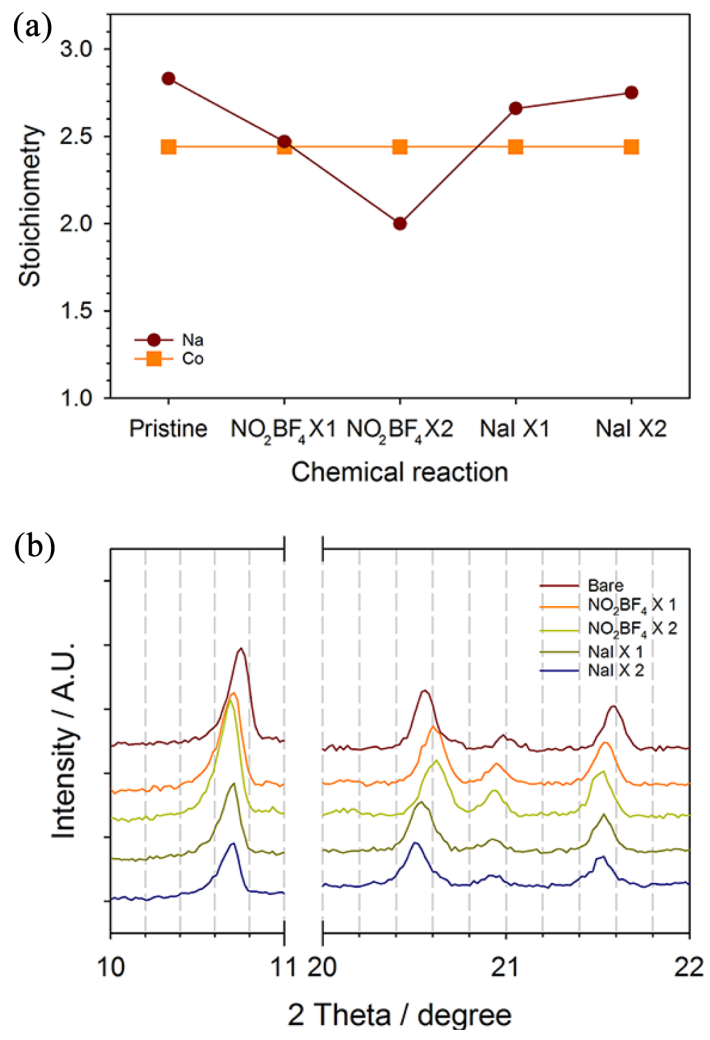

Fig. 7. (a) Atomic composition (ICP-MS) of $\mathrm{Na}_{3.12} \mathrm{Co}_{2.44}\left(\mathrm{P}_{2} \mathrm{O}_{7}\right)_{2}$ during repetitive chemical desodiation with $\mathrm{NO}_{2} \mathrm{BF}_{4}$ and sodiation with $\mathrm{NaI}$, and (b) the corresponding XRD patterns of $\mathrm{Na}_{3.12} \mathrm{Co}_{2.44}\left(\mathrm{P}_{2} \mathrm{O}_{7}\right)_{2}$ during chemical desodiation and sodiation. Numbers in legends indicate the number of repeating times for chemical desodiation and sodiation, respectively.

\section{Conclusions}

We synthesized two types of sodium cobalt pyrophosphates, triclinic $\mathrm{Na}_{3.12} \mathrm{Co}_{2.44}\left(\mathrm{P}_{2} \mathrm{O}_{7}\right)_{2}$ and orthorhombic $\mathrm{Na}_{2} \mathrm{CoP}_{2} \mathrm{O}_{7}$, through a conventional solid-state method via heating at $600^{\circ} \mathrm{C}$ under $\mathrm{Ar}$. $\mathrm{Na}_{3.12} \mathrm{Co}_{2.44}\left(\mathrm{P}_{2} \mathrm{O}_{7}\right)_{2}$ and $\mathrm{Na}_{2} \mathrm{CoP}_{2} \mathrm{O}_{7}$ were examined as high-voltage cathode materials for $\mathrm{Na}$-ion batteries. Whereas $\mathrm{Na}_{2} \mathrm{CoP}_{2} \mathrm{O}_{7}$ showed no electrochemical activity, $\mathrm{Na}_{3.12} \mathrm{Co}_{2.44}\left(\mathrm{P}_{2} \mathrm{O}_{7}\right)_{2}$ exhibited good electrochemical performance, such as high redox potential at $c a .4 .3 \mathrm{~V}\left(\mathrm{vs} . \mathrm{Na} / \mathrm{Na}^{+}\right.$) and stable capacity retention over 50 cycles, although $\mathrm{Na}_{3.12} \mathrm{Co}_{2.44}\left(\mathrm{P}_{2} \mathrm{O}_{7}\right)_{2}$ delivered approximately $40 \mathrm{~mA} \mathrm{~h} \mathrm{~g}^{-1}$. This is attributed to the fact that $\mathrm{Na}_{2} \mathrm{CoP}_{2} \mathrm{O}_{7}(\sim 3.1 \AA)$ has smaller diffusion channel size than $\mathrm{Na}_{3.12} \mathrm{Co}_{2.44}\left(\mathrm{P}_{2} \mathrm{O}_{7}\right)_{2}(\sim 4.2$
$\AA$ ). Moreover, we compared the electrochemical performances of $\mathrm{Na}_{3.12} \mathrm{Co}_{2.44}\left(\mathrm{P}_{2} \mathrm{O}_{7}\right)_{2}$ between $\mathrm{Na}$ cells and Li cells. Na cells showed smaller overpotential than Li cells. This is due to the fact that $\mathrm{Na}_{3.12} \mathrm{Co}_{2.44}\left(\mathrm{P}_{2} \mathrm{O}_{7}\right)_{2}$ displayed a smaller charge transfer resistance and higher diffusivity for $\mathrm{Na}^{+}$ions when compared to $\mathrm{Li}^{+}$ions. This implies that the large channel size of $\mathrm{Na}_{3.12} \mathrm{Co}_{2.44}\left(\mathrm{P}_{2} \mathrm{O}_{7}\right)_{2}$ were more appropriate for $\mathrm{Na}^{+}$ions than $\mathrm{Li}^{+}$ions. Therefore, $\mathrm{Na}_{3.12} \mathrm{Co}_{2.44}\left(\mathrm{P}_{2} \mathrm{O}_{7}\right)_{2}$ is considered a promising candidate for a high-voltage cathode material. We believe that the high energy density of $\mathrm{Na}$-ion batteries can be achieved with $\mathrm{Na}_{3.12} \mathrm{Co}_{2.44}\left(\mathrm{P}_{2} \mathrm{O}_{7}\right)_{2}$ if stable electrolytes above $4.5 \mathrm{~V}$ vs. $\mathrm{Na} / \mathrm{Na}^{+}$are developed.

\section{Acknowledgment}

This work was supported in part by the National Research Foundation of Korea (NRF) grant funded by the Korea government (MSIT) (2019R1A2B5B03070673).

\section{References}

[1] Ellis, B. L., Nazar, L. F., Curr. Opin. Solid. St. M., 2012, 16(4), 168-177.

[2] Palomares, V., Serras, P., Villaluenga, I., Hueso, K. B., Carretero-Gonzalez, J., Rojo, T., Energy Environ. Sci., 2012, 5(3), 5884-5901.

[3] Slater, M. D., Kim, D., Lee, E., Johnson, C. S., $A d v$ Funct Mater, 2013, 23(8), 947-958.

[4] Hong, S. Y., Kim, Y., Park, Y., Choi, A., Choi, N. S., Lee, K. T., Energy Environ. Sci., 2013, 6(7), 2067-2081.

[5] Braconnier, J. J., Delmas, C., Fouassier, C., Hagenmuller, P., Mater. Res. Bull., 1980, 15(12), $1797-$ 1804.

[6] Berthelot, R., Carlier, D., Delmas, C., Nat. Mater, 2011, 10(1), 74-80.

[7] Braconnier, J. J., Delmas, C., Hagenmuller, P., Mater. Res. Bull., 1982, 17(8), 993-1000.

[8] Takeda, Y., Nakahara, K., Nishijima, M., Imanishi, N., Yamamoto, O., Takano, M., Kanno, R., Mater. Res. Bull., 1994, 29(6), 659-666.

[9] Didier, C., Guignard, M., Darriet, J., Delmas, C., Inorg. Chem., 2012, 51(20), 11007-11016.

[10] Guignard, M., Didier, C., Darriet, J., Bordet, P., Elkaim, E., Delmas, C., Nat. Mater., 2013, 12(1), 74-80.

[11] Sauvage, F., Laffont, L., Tarascon, J. M., Baudrin, E., Inorg. Chem., 2007, 46(8), 3289-3294.

[12] Yabuuchi, N., Kajiyama, M., Iwatate, J., Nishikawa, H., Hitomi, S., Okuyama, R., Usui, R., Yamada, Y., Komaba, S., Nat. Mater, 2012, 11(6), 512-517.

[13] Komaba, S., Yabuuchi, N., Nakayama, T., Ogata, A., Ishikawa, T., Nakai, I., Inorg. Chem., 2012, 51(11), 
6211-6220

[14] Sathiya, M., Hemalatha, K., Ramesha, K., Tarascon, J. M., Prakash, A. S., Chem. Mater, 2012, 24(10), 18461853.

[15] Tripathi, R., Wood, S. M., Islam, M. S., Nazar, L. F., Energy Environ. Sci., 2013, 6(8), 2257-2264.

[16] Ellis, B. L., Makahnouk, W. R. M., RowanWeetaluktuk, W. N., Ryan, D. H., Nazar, L. F., Chem. Mater, 2010, 22(3), 1059-1070.

[17] Barker, J., Saidi, M. Y., Swoyer, J. L., Electrochem. Solid. St., 2003, 6(1), A1-A4.

[18] Sauvage, F., Quarez, E., Tarascon, J. M., Baudrin, E., Solid. State. Sci., 2006, 8(10), 1215-1221.

[19] Gover, R. K. B., Bryan, A., Burns, P., Barker, J., Solid. State. Ion., 2006, 177(17-18), 1495-1500.

[20] Yuvaraj, S., Oh, W., Yoon, W. S., J. Electrochem. Sci. Te., 2019, 10(1), 1-13.

[21] Trad, K., Carlier, D., Croguennec, L., Wattiaux, M., Lajmi, B., Ben Amara, M., Delmas, C., J. Phys. Chem. C., 2010, 114(21), 10034-10044.

[22] Kim, H., Shakoor, R. A., Park, C., Lim, S. Y., Kim, J. S., Jo, Y. N., Cho, W., Miyasaka, K., Kahraman, R., Jung, Y., Choi, J. W., Adv. Funct. Mater., 2013, 23(9), 1147-1155.

[23] Barpanda, P., Liu, G., Avdeev, M., Yamada, A., Chem. Electrochem., 2014, 1(9), 1488-1491.

[24] Barpanda, P., Ye, T., Avdeev, M., Chung, S. C., Yamada, A., J. Mater. Chem. A., 2013, 1(13), 4194-4197.

[25] Park, C. S., Kim, H., Shakoor, R. A., Yang, E., Lim, S. Y., Kahraman, R., Jung, Y., Choi, J. W., J. Am. Chem. Soc., 2013, 135(7), 2787-2792.

[26] Ha, K.-H., Woo, S. H., Mok, D., Choi, N.-S., Park, Y., Oh, S. M., Kim, Y., Kim, J., Lee, J., Nazar, L. F., Lee,
K. T., Adv. Energy Mater, 2013, 3(6), 770-776.

[27] Niu, Y. B., Xu, M. W., Cheng, C. J., Bao, S. J., Hou, J. K., Liu, S. G., Yi, F. L., He, H., Li, C. M., J. Mater Chem. A., 2015, 3(33), 17224-17229.

[28] Chen, C. Y., Matsumoto, K., Nohira, T., Hagiwara, R., J. Electrochem. Soc., 2015, 162(1), A176-A180.

[29] Vadivel Murugan, A., Muraliganth, T., Manthiram, A., J. Electrochem. Soc., 2009, 156(2), A79-A83.

[30] Erragh, F., Boukhari, A., Elouadi, B., Holt, E. M., J. Cryst Spectrosc., 1991, 21(3), 321-326.

[31] Sanz, F., Parada, C., Rojo, J. M., Ruiz-Valero, C., SaezPuche, R., J. Solid State Chem., 1999, 145(2), 604-611.

[32] Beaury, L., Derouet, J., Binet, L., Sanz, F., Ruiz-Valero, C., J. Solid State Chem., 2004, 177(4-5), 1437-1443.

[33] Barpanda, P., Lu, J. C., Ye, T., Kajiyama, M., Chung, S. C., Yabuuchi, N., Komaba, S., Yamada, A., Rsc. Adv., 2013, 3(12), 3857-3860.

[34] Song, Y. M., Han, J. G., Park, S., Lee, K. T., Choi, N. S., J. Mater. Chem. A., 2014, 2(25), 9506-9513.

[35] Levi, M. D., Aurbach, D., J. Phys. Chem. B., 1997, 101(23), 4641-4647.

[36] Levi, M. D., Levi, E. A., Aurbach, D., J. Electroanal. Chem., 1997, 421(1-2), 89-97.

[37] Ura, H., Nishina, T., Uchida, I., J. Electroanal. Chem., 1995, 396(1-2), 169-173.

[38] Tofield, B. C., Farrington, G. C., Nature, 1979, 278(5703), 438-439.

[39] Farrington, G. C., Dunn, B. S., Briant, J. L., Solid. State. Ion., 1981, 3, 405-408.

[40] Briant, J. L., Farrington, G. C., J. Electrochem. Soc., 1981, 128(9), 1830-1834.

[41] Wizansky, A. R., Rauch, P. E., Disalvo, F. J., J. Solid. State Chem., 1989, 81(2), 203-207. 